Article

\title{
Effect of Carbon Nanoadditives on Lithium Hydroxide Monohydrate-Based Composite Materials for Low Temperature Chemical Heat Storage
}

\author{
Xixian Yang ${ }^{1,+}$, Shijie Li ${ }^{1,2,+}$, Hongyu Huang ${ }^{1, *}, \mathrm{Jun} \mathrm{Li}^{3}$, Noriyuki Kobayashi ${ }^{3}$ \\ and Mitsuhiro Kubota ${ }^{3}$ \\ 1 Key Laboratory of Renewable Energy, Guangzhou Institute of Energy Conversion, Chinese Academy of \\ Sciences, No. 2 Nengyuan Rd., Wushan, Tianhe District, Guangzhou 510640, China; \\ yangxx@ms.giec.ac.cn (X.Y.); lisj@ms.giec.ac.cn (S.L.) \\ 2 University of Chinese Academy of Sciences, Beijing 100049, China \\ 3 Department of Engineering, Nagoya University, Furo-cho, Chikusa-ku, Nagoya-shi, Aichi 464-8603, Japan; \\ Junli@energy.gr.jp (J.L.); kobayashi@energy.gr.jp (N.K.); kubota@nuce.nagoya-u.ac.jp (M.K.) \\ * Correspondence: huanghy@ms.giec.ac.cn; Tel.: +86-20-870-48394 \\ $\dagger$ These two authors contribute equally to this work.
}

Academic Editor: Rui Xiong

Received: 5 April 2017; Accepted: 3 May 2017; Published: 6 May 2017

\begin{abstract}
Carbon nanospheres (CNSs) and multi-walled carbon nanotubes (MWCNTs) as nanoadditives were used to modify lithium hydroxide monohydrate for low temperature chemical heat storage application. The lithium hydroxide monohydrate particles were well dispersed on the nanoscale level, and the diameter of nanoparticles was about 20-30 nm in the case of the carbon nanospheres and 50-100 nm the case of the MWCNTs, as shown by transmission electron microscopy characterization results. X-ray diffraction results indicated that the $\mathrm{LiOH} \cdot \mathrm{H}_{2} \mathrm{O}$-carbon nano thermochemical composite materials were successfully synthesized. The thermochemical composite materials $\mathrm{LiOH} \cdot \mathrm{H}_{2} \mathrm{O} / \mathrm{CNSs}(2020 \mathrm{~kJ} / \mathrm{kg}), \mathrm{LiOH} \cdot \mathrm{H}_{2} \mathrm{O} / \mathrm{MWCNTs}(1804 \mathrm{~kJ} / \mathrm{kg})$, and $\mathrm{LiOH} \cdot \mathrm{H}_{2} \mathrm{O} / \mathrm{AC}$ $(1236 \mathrm{~kJ} / \mathrm{kg})$ exhibited obviously improved heat storage density and higher hydration rate than pure $\mathrm{LiOH} \cdot \mathrm{H}_{2} \mathrm{O}(661 \mathrm{~kJ} / \mathrm{kg})$, which was shown by thermogravimetric and differential scanning calorimetric (TG-DSC) analysis. It appears that nanocarbon-modified lithium hydroxide monohydrate thermochemical composite materials have a huge potential for the application of low temperature chemical heat storage.
\end{abstract}

Keywords: nanoparticles; energy storage and conversion; lithium hydroxide monohydrate; carbon nanoadditives

\section{Introduction}

In recent years, due to the consumption of fossil energy and global warming, thermal energy storage technologies have become more and more attractive and have been seriously considered as an important part of efficient utilization of alternative energy [1,2]. These technologies include three main type: sensible heat storage, latent heat storage and chemical heat storage. All of these technologies play a role in solving the supply and demand mismatching of thermal energy and improve energy efficiency [3]. Among these technologies, thermochemical heat storage, which uses reversible chemical reactions to store and release thermal energy, is more suitable for the efficient utilization of thermal energy due to the high heat storage density of thermochemical materials [4]. Based on the heat storage working temperature, thermochemical heat storage technology could be generally divided into two parts: high temperature heat storage $\left(200-1100^{\circ} \mathrm{C}\right)$ and low temperature heat storage $\left(<200{ }^{\circ} \mathrm{C}\right)[3,4]$. As one of the core parts of these technologies, a large number of thermochemical 
materials (TCMs) have been selected. For instance, metal hydroxides, metal hydrides, and metal carbonates can be used as TCMs for high temperature thermochemical heat storage, while inorganic salt hydrates and salt ammoniate are considered the promising candidates for low temperature thermochemical heat storage due to their different decomposition temperatures [5-10]. In order to efficiently store low temperature thermal energy, the inorganic hydrate $\mathrm{LiOH} \cdot \mathrm{H}_{2} \mathrm{O}$, which has a high energy density $(1440 \mathrm{~kJ} / \mathrm{kg})$ and mild reaction process, was selected as the most promising candidate [11]. However, just like other inorganic hydrates [12,13], both the hydration rate and thermal conductivity of pure $\mathrm{LiOH} \cdot \mathrm{H}_{2} \mathrm{O}$ are still low $[9,11]$, which seriously limits the application of this material. Hence, the preparation of heat storage composite TCMs with strong water sorption and high thermal conductivity is of great importance. Carbon nanotubes (CNTs) and carbon nanospheres (CNSs) are both typical carbon nanomaterials, which exhibit large surface area, high thermal conductivity, low bulk density and chemical stability [14-16], and they are widely used in many different fields such as electronics $[17,18]$, catalysis $[19,20]$ and latent heat thermal energy storage $[2,21,22]$. In addition, as a traditional macro carbon material, activated carbon (AC) also shows many good properties such as high adsorption capacity, high stability and low density, which are commonly used for gas adsorption [23] and catalyst synthesis [24]. Furthermore, all of these carbon materials are also substances with excellent hydrophilic properties after the introduction of surface oxygen groups. However, so far, carbon nanomaterials are rarely applied in the synthesis of inorganic hydrate-based TCMs. In our present work, in order to investigate the effect of carbon nanomaterials on the thermal energy storage performance of lithium hydroxide monohydrate, four kinds of TCMs $\left(\mathrm{LiOH} \cdot \mathrm{H}_{2} \mathrm{O}\right.$, $\mathrm{LiOH} \cdot \mathrm{H}_{2} \mathrm{O} / \mathrm{CNSs}, \mathrm{LiOH} \cdot \mathrm{H}_{2} \mathrm{O} / \mathrm{MWCNTs}, \mathrm{LiOH} \cdot \mathrm{H}_{2} \mathrm{O} / \mathrm{AC}$ ) were prepared. Among these samples, pure $\mathrm{LiOH} \cdot \mathrm{H}_{2} \mathrm{O}$ and activated carbon-modified $\mathrm{LiOH} \cdot \mathrm{H}_{2} \mathrm{O}\left(\mathrm{LiOH} \cdot \mathrm{H}_{2} \mathrm{O} / \mathrm{AC}\right)$ were used as control groups to obviously show the advantage of carbon nanomaterial-modified $\mathrm{LiOH} \cdot \mathrm{H}_{2} \mathrm{O}$.

\section{Materials and Methods}

\subsection{The Raw Materials and Synthesis Method of Lithium Hydroxide Monohydrate-Based TCMs}

CNSs were prepared according to the method described in Reference [25]. Firstly, $0.66 \mathrm{~g}$ resorcin (Aladdin Ltd., Shanghai, China), 0.6 g Pluronic F-127 (Shanghai yuanye Ltd., Shanghai, China) and $876 \mu \mathrm{L}$ formaldehyde solution (concentration $37 \%$, Tianjin damao chemical reagent company, Tianjin, China) were added to $800 \mathrm{~mL}$ deionized water under vigorous stirring at $5{ }^{\circ} \mathrm{C}$ for $30 \mathrm{~min}$. Then, this mixture was refluxed at $80^{\circ} \mathrm{C}$ for $8 \mathrm{~h}$. The solution was separated by centrifugation and then the phenol formaldehyde resin was obtained. After that, the phenol formaldehyde resin was moved into the tubular furnace and calcinated at $400{ }^{\circ} \mathrm{C}$ under $\mathrm{N}_{2}$ atmosphere for $3 \mathrm{~h}$, following which the temperature was raised to $800^{\circ} \mathrm{C}$ and maintained for $2 \mathrm{~h}$. After being cooled naturally to room temperature, the obtained product was oxidized by nitric acid (Guangzhou chemical reagent company, Guangzhou, China) for $2 \mathrm{~h}$ under reflux and continuous stirring at $120^{\circ} \mathrm{C}$. Finally, CNSs were obtained. The carbon nanotubes were synthesized by the catalytic chemical vapor deposition method using $\mathrm{CH}_{4}$ (Huate gas Ltd., Foshan, China) as a carbon source and nickel foam (Shanghai Zhonghui Foam Aluminum Co., Ltd., Shanghai, China) as a catalyst. Firstly, nickel foam was moved into the muffle furnace and oxidized at $700{ }^{\circ} \mathrm{C}$ for $1 \mathrm{~h}$ under an air atmosphere. Then, the nickel foam was placed into the tubular furnace and the temperature was raised to $700{ }^{\circ} \mathrm{C}$ and $\mathrm{Ar} / \mathrm{H}_{2}(300 \mathrm{~mL} / 100 \mathrm{~mL})$ mixed reducing gas was introduced into the furnace for $2 \mathrm{~h}$. After reduction, $\mathrm{Ar} / \mathrm{H}_{2}$ mixed gas was exchanged to $\mathrm{Ar} / \mathrm{CH}_{4}(400 \mathrm{~mL} / 100 \mathrm{~mL})$, the temperature was raised to $750{ }^{\circ} \mathrm{C}$ and the mixture was allowed to react for $20 \mathrm{~min}$. After the temperature had decreased to $25^{\circ} \mathrm{C}$, the obtained substance was then also oxidized by nitric acid for $2 \mathrm{~h}$ under reflux and continuous stirring at $120^{\circ} \mathrm{C}$. Finally, carbon nanotubes (MWCNTs) were obtained. The activated carbon was supplied by Sinopharm Chemical Reagent Co., Ltd. (Shanghai, China) and oxidized by nitric acid for $2 \mathrm{~h}$ under reflux and continuous stirring at $120^{\circ} \mathrm{C}$. The as-prepared carbon nanospheres, carbon nanotubes and activated carbon were composed with lithium hydroxide monohydrate (Aladdin Ltd., Shanghai, China) by the impregnation 
method. Firstly, $0.5 \mathrm{~g}$ lithium hydroxide monohydrate was dissolved in $1 \mathrm{~mL}$ deionized water under vigorous stirring, and then $0.5 \mathrm{~g}$ carbon nanospheres, carbon nanotubes and activated carbon were added to the lithium hydroxide aqueous solution at room temperature and stirred continually for $4 \mathrm{~h}$, separately. After that, the products were taken out and vacuum freeze-dried.

\subsection{The Characterization and Heat Storage Performance Test Method of Lithium Hydroxide Monohydrate-Based TCMs}

The surface topography was measured by field-emission scanning electron microscopy (SEM, S-4800, Hitachi Limited, Tokyo, Japan). Transmission electron micrographs (TEM) were obtained with an FEI Tecnai G212 operated at 100 kV and a JEOL JEM-2100F (Japan Electron Optics Laboratory Co., Ltd., Tokyo, Japan) operated at $200 \mathrm{kV}$. X-ray diffraction (XRD) analysis was performed on a D8-advance X-ray diffractometer (German Bruker, Karlsruhe, Germany) with Cu target ( $40 \mathrm{kV}, 40 \mathrm{~mA})$. The scan step size was $0.0167^{\circ}$ and the counting time was $10.160 \mathrm{~s}$. Nitrogen adsorption-desorption was measured at the boiling point of nitrogen (77 K) using a Quantachrome QDS-30 analyzer (Quantachrome Instruments, Boynton Beach, FL, USA). Brunauer-Emmett-Teller surface area and pore structure were measured by nitrogen physisorption under the normal relative pressure of $0.1-1.0$. The thermal conductivity of the sample was measured by a DRL-II thermal conductivity tester (Xiangtan Xiangyi Instrument co., Ltd., Xiangtan, China). After hydration, samples were dissolved in hot concentrated hydrochloric acid (Guangzhou chemical reagent company, Guangzhou, China). After cooling to room temperature, the solution was diluted with ultrapure water and analyzed for the lithium content by atomic absorption spectroscopy (AAS, Thermo Scientific S4AA, Thermo Fisher Scientific, Waltham, MA, USA). $\mathrm{LiOH} \cdot \mathrm{H}_{2} \mathrm{O}, \mathrm{LiOH} \cdot \mathrm{H}_{2} \mathrm{O} / \mathrm{CNSs}, \mathrm{LiOH} \cdot \mathrm{H}_{2} \mathrm{O} /$ MWCNTs, $\mathrm{LiOH} \cdot \mathrm{H}_{2} \mathrm{O} / \mathrm{AC}$ were used as raw substances. Then, $\mathrm{LiOH}$ and $\mathrm{LiOH} / \mathrm{CNSs}, \mathrm{LiOH} / \mathrm{MWCNTs}$, and $\mathrm{LiOH} / \mathrm{AC}$ were synthesized by the decomposition of $\mathrm{LiOH} \cdot \mathrm{H}_{2} \mathrm{O}, \mathrm{LiOH} \cdot \mathrm{H}_{2} \mathrm{O} / \mathrm{CNSs}, \mathrm{LiOH} \cdot \mathrm{H}_{2} \mathrm{O} / \mathrm{MWCNTs}, \mathrm{LiOH} \cdot \mathrm{H}_{2} \mathrm{O} / \mathrm{AC}$ in a horizontal tubular quartz furnace with Ar gas at $150{ }^{\circ} \mathrm{C}$ for $3 \mathrm{~h}$. Dehydrated products were also cooled to $30^{\circ} \mathrm{C}$ in the Ar atmosphere, and water vapor with $2.97 \mathrm{kPa}$ of partial pressure carried with $\mathrm{N}_{2}$ flow was introduced into the tube for $60 \mathrm{~min}$ as a hydration operation at $30^{\circ} \mathrm{C}$. After the hydration operation, the endothermic heat and temperature of the samples were measured with the thermo gravimetric and differential thermal analyzer (STA-200, Nanjingdazhan co., Ltd., Nanjing, China), which was also used for measuring the weight change during the dehydration step at the same time. Each TG-DSC measurement was repeated three times in order to ensure correctness.

\section{Results and Discussion}

\subsection{The Microstructure Characterization of Lithium Hydroxide Monohydrate-Based TCMs}

Figure 1 shows the XRD patterns of $\mathrm{LiOH} \cdot \mathrm{H}_{2} \mathrm{O}, \mathrm{LiOH} \cdot \mathrm{H}_{2} \mathrm{O} / \mathrm{CNSs}, \mathrm{LiOH} \cdot \mathrm{H}_{2} \mathrm{O} / \mathrm{MWCNTs}$, and $\mathrm{LiOH} \cdot \mathrm{H}_{2} \mathrm{O} / \mathrm{AC}$, as well as the CNS, MWCNT, and AC samples. As shown in Figure 1, the diffraction peaks at around $20^{\circ}, 22^{\circ}, 30^{\circ}, 32.19^{\circ}, 33.64^{\circ}, 34.84^{\circ}, 37.07^{\circ}, 38.83^{\circ}, 40.06^{\circ}, 41.61^{\circ}, 43.49^{\circ}, 49.37^{\circ}, 51.36^{\circ}$, $52.47^{\circ}, 55.15^{\circ}, 55.70^{\circ}, 56.92^{\circ}, 62.15^{\circ}, 63.13^{\circ}, 64.55^{\circ}, 65.47^{\circ}, 66.22^{\circ}, 68.35^{\circ}$ and $71.34^{\circ}$, respectively, were attributed to $\mathrm{LiOH} \cdot \mathrm{H}_{2} \mathrm{O}$. In addition, the diffraction peaks at around $25^{\circ}$ and $43^{\circ}$ were attributed to graphitic carbon [26].

The broad diffraction peaks of $\mathrm{LiOH} \cdot \mathrm{H}_{2} \mathrm{O} / \mathrm{CNSs}, \mathrm{LiOH} \cdot \mathrm{H}_{2} \mathrm{O} / \mathrm{MWCNTs}$, and $\mathrm{LiOH} \cdot \mathrm{H}_{2} \mathrm{O} / \mathrm{AC}$ indicated that $\mathrm{LiOH} \cdot \mathrm{H}_{2} \mathrm{O}$ were well dispersed on CNSs, MWCNTs, and AC. Figure 2a-f provide the SEM images of CNSs, MWCNTs, $\mathrm{LiOH} \cdot \mathrm{H}_{2} \mathrm{O}, \mathrm{LiOH} \cdot \mathrm{H}_{2} \mathrm{O} / \mathrm{CNSs}, \mathrm{LiOH} \cdot \mathrm{H}_{2} \mathrm{O} / \mathrm{MWCNTs}$ and $\mathrm{LiOH} \cdot \mathrm{H}_{2} \mathrm{O} / \mathrm{AC}$, respectively.

From the SEM analysis, it was confirmed that highly uniform CNSs (Figure 2a) with diameters of $200 \mathrm{~nm}$ were successfully synthesized, and MWCNTs (Figure 2b) with diameters of around $100 \mathrm{~nm}$ were also successfully prepared. Before the doping of the carbon additives, the bulk $\mathrm{LiOH} \cdot \mathrm{H}_{2} \mathrm{O}$ (Figure 2c) was aggregated with large diameters $(300 \mathrm{~nm}-1 \mu \mathrm{m}) . \mathrm{LiOH} \cdot \mathrm{H}_{2} \mathrm{O}$ particles were well supported and dispersed on the surface of the carbon nanospheres (Figure 2d) and carbon nanotubes 
(Figure 2e). Furthermore, no obvious structure deterioration could be observed after the introduction of $\mathrm{LiOH} \cdot \mathrm{H}_{2} \mathrm{O}$. However, the surface of the activated carbon (Figure 2f) was intensively covered after the intervention of $\mathrm{LiOH} \cdot \mathrm{H}_{2} \mathrm{O}$.

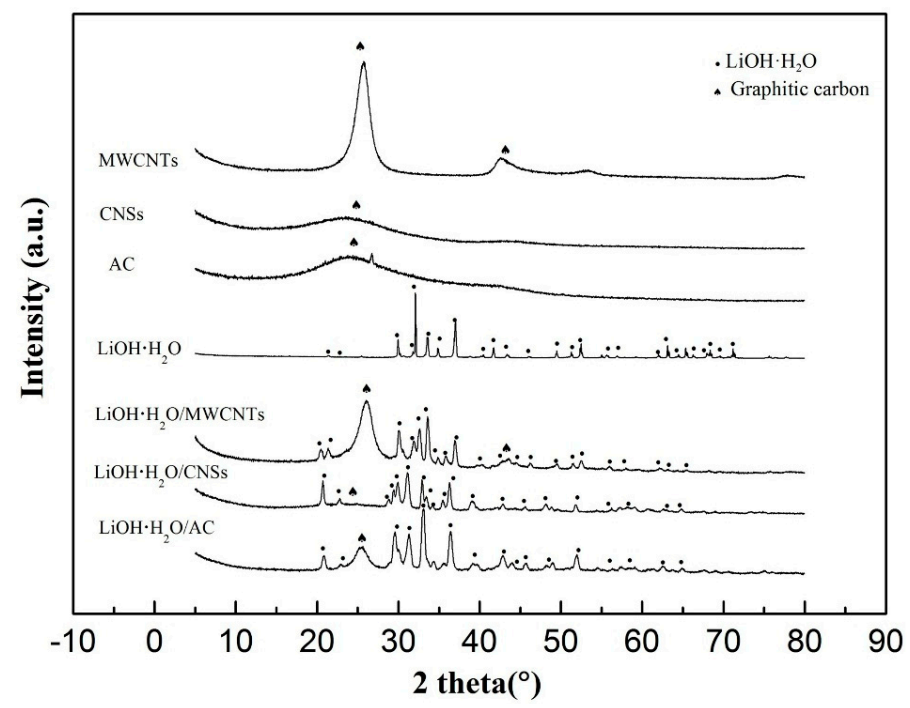

Figure 1. XRD patterns of MWCNTs, CNSs, activated carbon, $\mathrm{LiOH} \cdot \mathrm{H}_{2} \mathrm{O}, \mathrm{LiOH} \cdot \mathrm{H}_{2} \mathrm{O} / \mathrm{MWCNTs}$, $\mathrm{LiOH} \cdot \mathrm{H}_{2} \mathrm{O} / \mathrm{CNSs}$ and $\mathrm{LiOH} \cdot \mathrm{H}_{2} \mathrm{O} / \mathrm{AC}$.
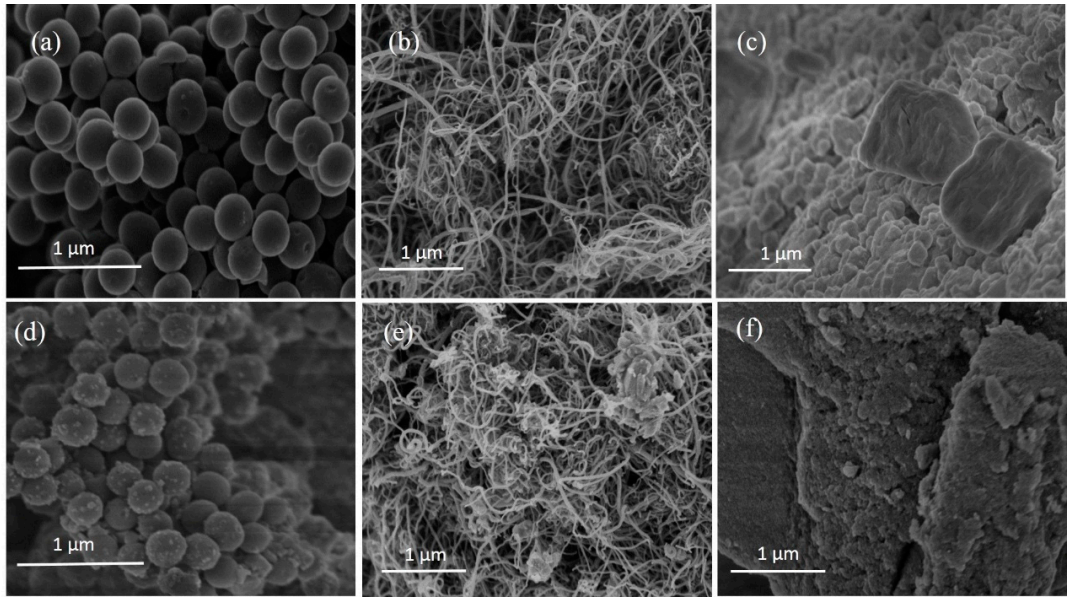

Figure 2. SEM images of (a) CNSs, (b) MWCNTs, (c) $\mathrm{LiOH} \cdot \mathrm{H}_{2} \mathrm{O}$, (d) $\mathrm{LiOH} \cdot \mathrm{H}_{2} \mathrm{O} / \mathrm{CNSs}$, (e) $\mathrm{LiOH} \cdot \mathrm{H}_{2} \mathrm{O} / \mathrm{MWCNTs}$; and (f) $\mathrm{LiOH} \cdot \mathrm{H}_{2} \mathrm{O} / \mathrm{AC}$.

Figure 3 shows the TEM images of (a) CNSs, (b) MWCNTs, (c) $\mathrm{LiOH} \cdot \mathrm{H}_{2} \mathrm{O}$, (d) $\mathrm{LiOH} \cdot \mathrm{H}_{2} \mathrm{O} / \mathrm{CNSs}$, (e) $\mathrm{LiOH} \cdot \mathrm{H}_{2} \mathrm{O} / \mathrm{MWCNTs}$ and (f) $\mathrm{LiOH} \cdot \mathrm{H}_{2} \mathrm{O} / \mathrm{AC}$. Compared with Figure 3a, it could be observed that the $\mathrm{LiOH} \cdot \mathrm{H}_{2} \mathrm{O}$ nanoparticles with a diameter of 20-30 nm were successfully supported on the CNSs (Figure 3d) with clear particle structures. Additionally, it was also well-supported on the MWCNTs (Figure 3e), but part of the $\mathrm{LiOH} \cdot \mathrm{H}_{2} \mathrm{O}$ nanoparticles were connected with others without a clear interface. The nanoparticle diameter was in the range of $50 \mathrm{~nm}$ to $100 \mathrm{~nm}$, which was a bit larger than that supported on the CNSs. As for the $\mathrm{LiOH} \cdot \mathrm{H}_{2} \mathrm{O} / \mathrm{AC}$ sample (Figure $3 \mathrm{f}$ ), no clear $\mathrm{LiOH} \cdot \mathrm{H}_{2} \mathrm{O}$ particles could be observed on the activated carbons. Also, the pure $\mathrm{LiOH} \cdot \mathrm{H}_{2} \mathrm{O}$ (Figure 3c) existed in the form of stacked flakes. The $\mathrm{LiOH} \cdot \mathrm{H}_{2} \mathrm{O}$ content of $\mathrm{LiOH} \cdot \mathrm{H}_{2} \mathrm{O} / \mathrm{CNSs}$, $\mathrm{LiOH} \cdot \mathrm{H}_{2} \mathrm{O} / \mathrm{MWCNTs}, \mathrm{LiOH} \cdot \mathrm{H}_{2} \mathrm{O} / \mathrm{AC}$ was about $50 \%$, as characterized by AAS. During the synthesis of $\mathrm{LiOH} \cdot \mathrm{H}_{2} \mathrm{O} / \mathrm{CNSs}$, $\mathrm{LiOH} \cdot \mathrm{H}_{2} \mathrm{O} / \mathrm{MWCNTs}$, and $\mathrm{LiOH} \cdot \mathrm{H}_{2} \mathrm{O} / \mathrm{AC}$, intermolecular interactions such as hydrogen bonding may exist between the additives and $\mathrm{LiOH} \cdot \mathrm{H}_{2} \mathrm{O}$, respectively, owing to 
the presence of oxygen-containing functional groups such as hydroxyl, carbonyl and carboxyl groups $[14,23,27]$ on the surface of the CNSs, MWCNTs and AC. Therefore, with the proper additives supplying hydrogen bonding, the composites could show a good ability for retarding the aggregation of $\mathrm{LiOH} \cdot \mathrm{H}_{2} \mathrm{O}$. The porosity structures of CNSs, MWCNTs, AC, $\mathrm{LiOH} \cdot \mathrm{H}_{2} \mathrm{O}, \mathrm{LiOH} \cdot \mathrm{H}_{2} \mathrm{O} / \mathrm{CNSs}$, $\mathrm{LiOH} \cdot \mathrm{H}_{2} \mathrm{O} / \mathrm{MWCNTs}$, and $\mathrm{LiOH} \cdot \mathrm{H}_{2} \mathrm{O} / \mathrm{AC}$ were also measured by nitrogen adsorption-desorption isotherms. The Brunauer-Emmett-Teller (BET) surface area, pore volume and average pore size are shown in Table 1 . As can be seen from Table 1, it was clear that the composed $\mathrm{LiOH} \cdot \mathrm{H}_{2} \mathrm{O}$-based TCMs exhibit different textures. Due to the larger BET surface area of the carbon nanoadditives, the specific surface area of $\mathrm{LiOH} \cdot \mathrm{H}_{2} \mathrm{O} / \mathrm{CNSs}\left(276 \mathrm{~m}^{2} / \mathrm{g}\right)$ and $\mathrm{LiOH} \cdot \mathrm{H}_{2} \mathrm{O} / \mathrm{MWCNTs}\left(140 \mathrm{~m}^{2} / \mathrm{g}\right)$ was higher than that of $\mathrm{LiOH} \cdot \mathrm{H}_{2} \mathrm{O} / \mathrm{AC}\left(84 \mathrm{~m}^{2} / \mathrm{g}\right)$ and pure $\mathrm{LiOH} \cdot \mathrm{H}_{2} \mathrm{O}\left(15 \mathrm{~m}^{2} / \mathrm{g}\right)$. According to the SEM and TEM characterization results, it can be concluded that high specific surface area was also an important factor that lead to the form of nanoscale dispersion of $\mathrm{LiOH} \cdot \mathrm{H}_{2} \mathrm{O}$ particles.
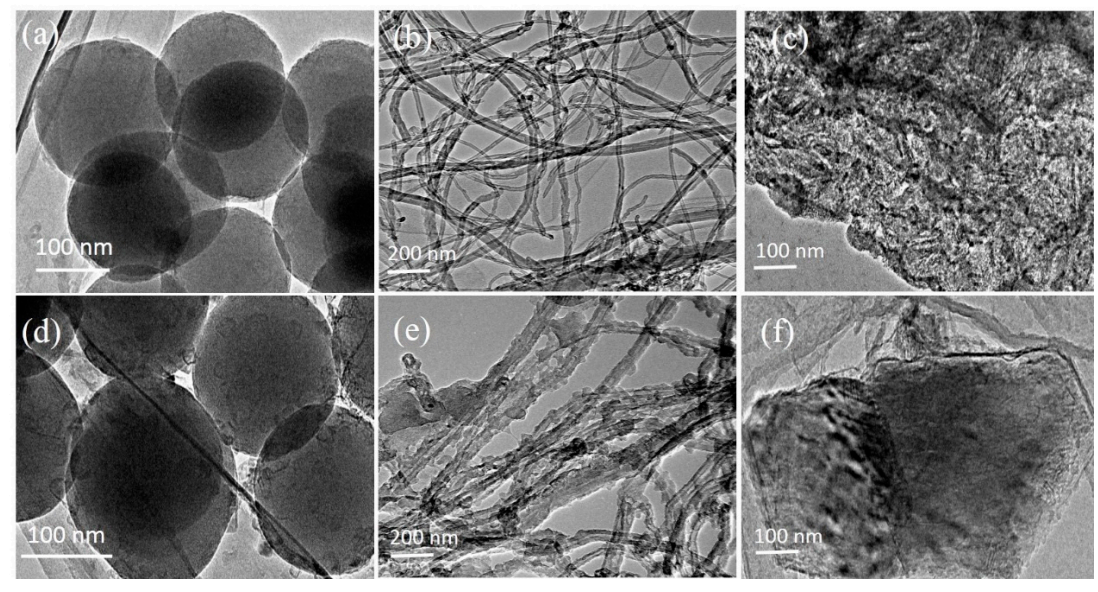

Figure 3. TEM images of (a) CNSs, (b) MWCNTs, (c) $\mathrm{LiOH} \cdot \mathrm{H}_{2} \mathrm{O}$, (d) $\mathrm{LiOH} \cdot \mathrm{H}_{2} \mathrm{O} / \mathrm{CNSs}$, (e) $\mathrm{LiOH} \cdot \mathrm{H}_{2} \mathrm{O} / \mathrm{MWCNTs}$ and (f) $\mathrm{LiOH} \cdot \mathrm{H}_{2} \mathrm{O} / \mathrm{AC}$.

Table 1. Texture parameters of carbon nanoadditive-modified thermal chemical materials CNSs, MWCNTs, AC, $\mathrm{LiOH} \cdot \mathrm{H}_{2} \mathrm{O} / \mathrm{CNSs}, \mathrm{LiOH} \cdot \mathrm{H}_{2} \mathrm{O} / \mathrm{MWCNTs}, \mathrm{LiOH} \cdot \mathrm{H}_{2} \mathrm{O} / \mathrm{AC}$ and pure $\mathrm{LiOH} \cdot \mathrm{H}_{2} \mathrm{O}$.

\begin{tabular}{cccc}
\hline Samples & BET Surface Area $\left(\mathbf{m}^{2} / \mathbf{g}\right)$ & Pore Volume $(\mathbf{m L} / \mathbf{g})$ & Average Pore Size $(\mathbf{n m})$ \\
\hline $\mathrm{CNSs}$ & 381 & 0.25 & 4.81 \\
$\mathrm{MWCNTs}$ & 343 & 0.61 & 8.95 \\
$\mathrm{AC}$ & 324 & 0.75 & 2.71 \\
$\mathrm{LiOH} \cdot \mathrm{H}_{2} \mathrm{O} / \mathrm{CNSs}$ & 276 & 0.18 & 2.64 \\
$\mathrm{LiOH} \cdot \mathrm{H}_{2} \mathrm{O} / \mathrm{MWCNTs}$ & 140 & 0.31 & 8.81 \\
$\mathrm{LiOH} \cdot \mathrm{H}_{2} \mathrm{O} / \mathrm{AC}$ & 84 & 0.03 & 2.54 \\
Pure $\mathrm{LiOH} \cdot \mathrm{H}_{2} \mathrm{O}$ & 15 & 0.06 & 1.75 \\
\hline
\end{tabular}

\subsection{The Heat Storage Performance Test of Lithium Hydroxide Monohydrate-Based TCMs}

Comparative performance tests of pure $\mathrm{LiOH} \cdot \mathrm{H}_{2} \mathrm{O}, \mathrm{LiOH} \cdot \mathrm{H}_{2} \mathrm{O} / \mathrm{AC}, \mathrm{LiOH} \cdot \mathrm{H}_{2} \mathrm{O} / \mathrm{CNSs}$ and $\mathrm{LiOH} \cdot \mathrm{H}_{2} \mathrm{O} / \mathrm{MWCNTs}$ were carried out, the results of which are shown in Figure 4. It was found that the reaction rate of lithium hydroxide and water vapor was slow and the conversion of $\mathrm{LiOH}$ to $\mathrm{LiOH} \cdot \mathrm{H}_{2} \mathrm{O}$ was only about $42 \%$ after $1 \mathrm{~h}$ hydration, which was calculated by the approximately $18 \%$ mass loss of $\mathrm{H}_{2} \mathrm{O}$, as shown in Figure $4 \mathrm{a}$. It was also found that the endothermic heat value of $\mathrm{LiOH} \cdot \mathrm{H}_{2} \mathrm{O}$ was only about $661 \mathrm{~kJ} / \mathrm{kg}$. Figure $4 \mathrm{~b}$ shows the DSC curve of CNS-modified $\mathrm{LiOH} \cdot \mathrm{H}_{2} \mathrm{O}$. It could be seen that after $1 \mathrm{~h}$ hydration of $\mathrm{LiOH} / \mathrm{CNSs}, \mathrm{LiOH}$ was fully hydrated to $\mathrm{LiOH} \cdot \mathrm{H}_{2} \mathrm{O}$ and, furthermore, the heat storage density of this sample normalized by $\mathrm{LiOH} \cdot \mathrm{H}_{2} \mathrm{O}$ content could reach $2020 \mathrm{~kJ} / \mathrm{kg}$. This value of $\mathrm{LiOH} \cdot \mathrm{H}_{2} \mathrm{O}$ contained in $\mathrm{LiOH} \cdot \mathrm{H}_{2} \mathrm{O} / \mathrm{MWCNTs}$ also reached a high level $(1804 \mathrm{~kJ} / \mathrm{kg})$, as shown in Figure 4c. As for the $\mathrm{LiOH} \cdot \mathrm{H}_{2} \mathrm{O} / \mathrm{AC}$ sample, the heat storage 
density of $\mathrm{LiOH} \cdot \mathrm{H}_{2} \mathrm{O}$ was lower than that of $\mathrm{LiOH} \cdot \mathrm{H}_{2} \mathrm{O} / \mathrm{MWCNTs}$ and $\mathrm{LiOH} \cdot \mathrm{H}_{2} \mathrm{O} / \mathrm{CNSs}$, and reached $1236 \mathrm{~kJ} / \mathrm{kg}$ (Figure $4 \mathrm{~d}$ ). It was indicated that at the same duration of the hydration reaction, due to the addition of CNSs, MWCNTs and AC, $\mathrm{LiOH}$ was fully reacted with $\mathrm{H}_{2} \mathrm{O}$ molecules and converted to $\mathrm{LiOH} \cdot \mathrm{H}_{2} \mathrm{O}$ compared with pure $\mathrm{LiOH}$. In other words, the hydration reaction rate of $\mathrm{LiOH} \cdot \mathrm{H}_{2} \mathrm{O} / \mathrm{CNSs}, \mathrm{LiOH} \cdot \mathrm{H}_{2} \mathrm{O} / \mathrm{MWCNTs}$ and $\mathrm{LiOH} \cdot \mathrm{H}_{2} \mathrm{O} / \mathrm{AC}$ were greatly enhanced. On one hand, the existing hydrophilic functional groups on the surface of CNSs, MWCNTs and AC could make $\mathrm{H}_{2} \mathrm{O}$ adsorption easier and provide a completely different reaction interface between $\mathrm{LiOH}$ and the water molecules. On the other hand, the reason that $\mathrm{LiOH} \cdot \mathrm{H}_{2} \mathrm{O} / \mathrm{CNSs}$ and $\mathrm{LiOH} \cdot \mathrm{H}_{2} \mathrm{O} / \mathrm{MWCNTs}$ composed TCMs showed ultrahigh heat storage density, higher than that of $\mathrm{LiOH} \cdot \mathrm{H}_{2} \mathrm{O} / \mathrm{AC}$ and pure $\mathrm{LiOH} \cdot \mathrm{H}_{2} \mathrm{O}$ TCMs, could be due to their higher specific surface area, which substantially enhanced the dispersion of $\mathrm{LiOH} \cdot \mathrm{H}_{2} \mathrm{O}$ nanoparticles and increased the contact of the surface area with the water molecules. Also, the low specific surface area of $\mathrm{LiOH} \cdot \mathrm{H}_{2} \mathrm{O} / \mathrm{AC}$ and pure $\mathrm{LiOH} \cdot \mathrm{H}_{2} \mathrm{O}$ may be the reason for their lower heat storage density. When the particle size reached the nanoscale, the amount of surface atoms would obviously increase; therefore, the crystalline field and binding energy of the internal atoms were different from that of the surface atoms, which have many dangling bonds due to the lack of adjacent atoms. So, owing to the unsaturated bonds in atoms, nanoparticles show better thermodynamic properties $[28,29]$. Meanwhile, due to the increase of surface atoms and their existing hydrophilic functional groups, a greater amount of $\mathrm{H}_{2} \mathrm{O}$ and $\mathrm{LiOH}$ was able to react, which in turn improved the heat storage performance of the composite. Furthermore, according to the TEM characterization results, the reason that the heat storage density of $\mathrm{LiOH} \cdot \mathrm{H}_{2} \mathrm{O} / \mathrm{CNSs}$ was higher than that of $\mathrm{LiOH} \cdot \mathrm{H}_{2} \mathrm{O} / \mathrm{MWCNTs}$ may be due to the smaller particle size of $\mathrm{LiOH} \cdot \mathrm{H}_{2} \mathrm{O}(20-30 \mathrm{~nm})$ that existed in $\mathrm{LiOH} \cdot \mathrm{H}_{2} \mathrm{O} / \mathrm{CNSs}$ compared to that in $\mathrm{LiOH} \cdot \mathrm{H}_{2} \mathrm{O} / \mathrm{MWCNTs}(50-100 \mathrm{~nm}$ ). It could be speculated that smaller size nanoparticles could make a greater contribution to the enhancement of heat storage density of TCMs. Additionally, after the addition of CNSs, MWCNTs and AC to LiOH. $\mathrm{H}_{2} \mathrm{O}$, the thermal conductivity of these composed TCMs became higher than that of pure $\mathrm{LiOH} \cdot \mathrm{H}_{2} \mathrm{O}$ (shown in Figure 5). Presently, the synthesis of carbon nanoadditive-modified, $\mathrm{LiOH} \cdot \mathrm{H}_{2} \mathrm{O}$-based thermochemical materials has not yet been fully developed, and the heat storage density of the inorganic hydrate could be further improved by controlling its hydrophilic property and particle size.
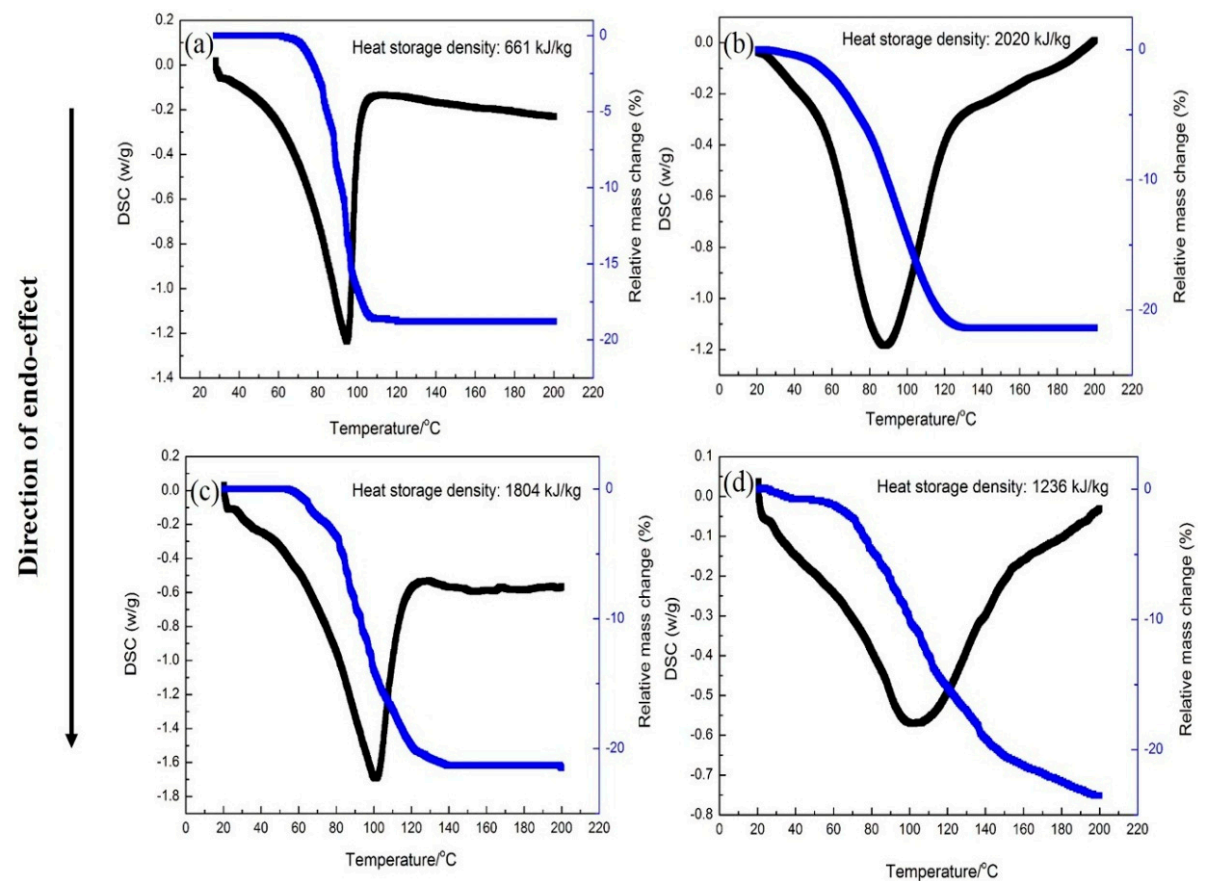

Figure 4. TG-DSC curves of as-synthesized samples: (a) pure LiOH after $1 \mathrm{~h}$ hydration, (b) $\mathrm{LiOH} / \mathrm{CNSs}$ after $1 \mathrm{~h}$ hydration, (c) LiOH/MWCNTs after $1 \mathrm{~h}$ hydration, and (d) LiOH/AC after $1 \mathrm{~h}$ hydration. 


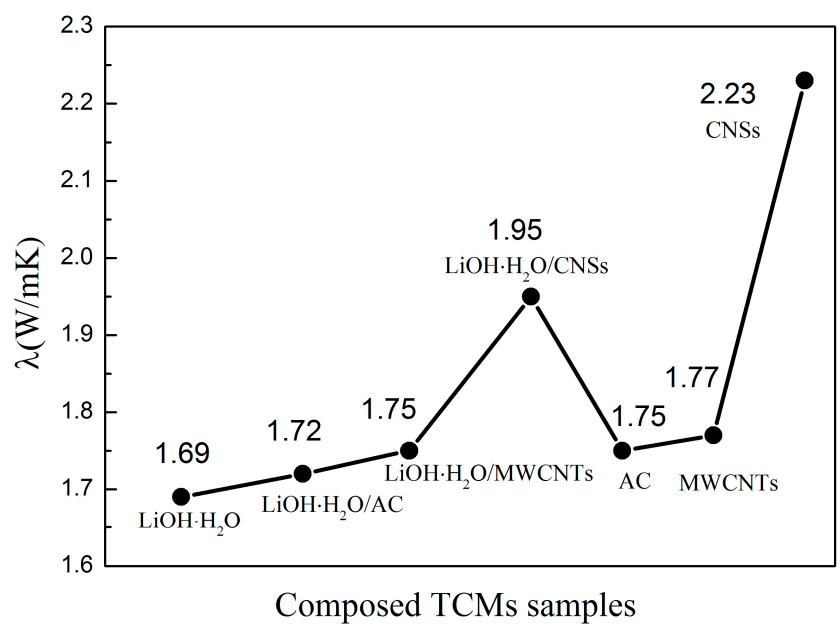

Figure 5. Thermal conductivity of CNSs, MWCNTs, AC, $\mathrm{LiOH} \cdot \mathrm{H}_{2} \mathrm{O}, \mathrm{LiOH} \cdot \mathrm{H}_{2} \mathrm{O} / \mathrm{CNSs}, \mathrm{LiOH} \cdot \mathrm{H}_{2} \mathrm{O} /$ MWCNTs and $\mathrm{LiOH} \cdot \mathrm{H}_{2} \mathrm{O} / \mathrm{AC}$.

\section{Conclusions}

To sum up, carbon nanoadditive-modified, $\mathrm{LiOH} \cdot \mathrm{H}_{2} \mathrm{O}$-based thermochemical materials were synthesized, characterized and well applied for low temperature chemical heat storage. The existence of carbon nanomaterials (CNSs and MWCNTs) in the $\mathrm{LiOH} \cdot \mathrm{H}_{2} \mathrm{O}$-based composite TCMs cause the $\mathrm{LiOH} \cdot \mathrm{H}_{2} \mathrm{O}$ particles to disperse into the nanoscale level and form different sizes of particles. The hydration reaction rates of the composed materials were greatly improved and the heat storage density of $\mathrm{LiOH} \cdot \mathrm{H}_{2} \mathrm{O}$ in the composed TCMs reached $2020 \mathrm{~kJ} / \mathrm{kg}$ and $1804 \mathrm{~kJ} / \mathrm{kg}$, respectively, which were much higher values than that of $\mathrm{LiOH} \cdot \mathrm{H}_{2} \mathrm{O} / \mathrm{AC}(1236 \mathrm{~kJ} / \mathrm{kg})$ and pure $\mathrm{LiOH} \cdot \mathrm{H}_{2} \mathrm{O}(661 \mathrm{~kJ} / \mathrm{kg})$. This may due to the hydrophilic property, high specific surface area and the nanoparticle size effect of the composed thermochemical materials. Finally, the additives also showed certain a positive effect on the thermal conductivity of the composed TCMs.

Acknowledgments: This work was supported by the National Science Foundation of China (No. 51406209).

Author Contributions: Xixian Yang and Shijie Li contributed equally to this work. They contributed to the material synthesis, data analysis and paper writing; Hongyu Huang and Jun Li contributed to the material characterization; Noriyuki Kobayashi and Mitsuhiro Kubota contributed to the design of the experiment.

Conflicts of Interest: The authors declare no conflict of interest.

\section{References}

1. Gil, A.; Medrano, M.; Martorell, I.; Lázaro, A.; Dolado, P.; Zalba, B.; Cabeza, L.F. State of the art on high temperature thermal energy storage for power generation. Part 1 -Concepts, materials and modellization. Renew. Sustain. Energy Rev. 2010, 14, 31-55. [CrossRef]

2. Tang, Q.; Sun, J.; Yu, S.; Wang, G. Improving thermal conductivity and decreasing supercooling of paraffin phase change materials by n-octadecylamine-functionalized multi-walled carbon nanotubes. RSC Adv. 2014, 4, 36584-36590. [CrossRef]

3. Yan, T.; Wang, R.Z.; Li, T.X.; Wang, L.W.; Fred, I.T. A review of promising candidate reactions for chemical heat storage. Renew. Sustain. Energy Rev. 2015, 43, 13-31. [CrossRef]

4. Pardo, P.; Deydier, A.; Anxionnaz-Minvielle, Z.; Rougé, S.; Cabassud, M.; Cognet, P. A review on high temperature thermochemical heat energy storage. Renew. Sustain. Energy Rev. 2014, 32, 591-610. [CrossRef]

5. Ishitobi, H.; Uruma, K.; Takeuchi, M.; Ryu, J.; Kato, Y. Dehydration and hydration behavior of metal-salt-modified materials for chemical heat pumps. Appl. Therm. Eng. 2013, 50, 1639-1644. [CrossRef]

6. Ogura, H.; Yamamoto, T.; Kage, H. Efficiencies of $\mathrm{CaO} / \mathrm{H}_{2} \mathrm{O} / \mathrm{Ca}(\mathrm{OH})_{2}$ chemical heat pump for heat storing and heating/cooling. Energy 2003, 28, 1479-1493. [CrossRef] 
7. Sheppard, D.A.; Paskevicius, M.; Buckley, C.E. Thermodynamics of hydrogen desorption from $\mathrm{NaMgH}_{3}$ and its application as a solar heat storage medium. Chem. Mater. 2011, 23, 4298-4300. [CrossRef]

8. Kyaw, K.; Shibata, T.; Watanabe, F.; Matsuda, H.; Hasatani, M. Applicability of zeolite for $\mathrm{CO}_{2}$ storage in a $\mathrm{CaO}-\mathrm{CO}_{2}$ high temperature energy storage system. Energy Convers. Manag. 1997, 38, 1025-1033. [CrossRef]

9. Yang, X.X.; Huang, H.Y.; Wang, Z.H.; Kubota, M.; He, Z.H.; Kobayashi, N. Facile synthesis of graphene oxide-modified lithium hydroxide for low-temperature chemical heat storage. Chem. Phys. Lett. 2016, 644, 31-34. [CrossRef]

10. Wongsuwan, W.; Kumar, S.; Neveu, P.; Meunier, F. A review of chemical heat pump technology and applications. Appl. Therm. Eng. 2001, 21, 1489-1519. [CrossRef]

11. Kubota, M.; Horie, N.; Togari, H.; Matsuda, H. Improvement of hydration rate of $\mathrm{LiOH} / \mathrm{LiOH} \cdot \mathrm{H} 2 \mathrm{O}$ reaction for low-temperature thermal energy storage. In Procceding of the 2013 Annual Meeting of Japan Society of Refrigerating and Air Conditioning Engineers, Tokyo, Japan, 10-12 September 2013.

12. Whiting, G.; Grondin, D.; Bennici, S.; Auroux, A. Heats of water sorption studies on zeolite- $\mathrm{MgSO}_{4}$ composites as potential thermochemical heat storage materials. Sol. Energy Mater. Sol. Cells 2013, 112, 112-119. [CrossRef]

13. Hongois, S.; Kuznik, F.; Stevens, P.; Roux, J.J. Development and characterisation of a new $\mathrm{MgSO}_{4}$-zeolite composite for long-term thermal energy storage. Sol. Energy Mater. Sol. Cells 2011, 95, 1831-1837. [CrossRef]

14. Mehrali, M.; Tahan Latibari, S.; Mehrali, M.; Mahlia, T.M.I.; Cornelis Metselaar, H.S. Effect of carbon nanospheres on shape stabilization and thermal behavior of phase change materials for thermal energy storage. Energy Convers. Manag. 2014, 88, 206-213. [CrossRef]

15. Balandin, A.A. Thermal properties of graphene and nanostructured carbon materials. Nat. Mater. 2011, 10, 569-581. [CrossRef] [PubMed]

16. Candelaria, S.L.; Shao, Y.; Zhou, W.; Li, X.; Xiao, J.; Zhang, J.G.; Wang, Y.; Liu, J.; Li, J.; Cao, G. Nanostructured carbon for energy storage and conversion. Nano Energy 2012, 1, 195-220. [CrossRef]

17. Cao, Q.; Rogers, J.A. Ultrathin films of single-walled carbon nanotubes for electronics and sensors: A review of fundamental and applied aspects. Adv. Mater. 2010, 21, 29-53. [CrossRef]

18. Cao, Q.; Han, S.J.; Tulevski, G.S.; Zhu, Y.; Lu, D.D.; Haensch, W. Arrays of single-walled carbon nanotubes with full surface coverage for high-performance electronics. Nat. Nanotechnol. 2013, 8, 180-186. [CrossRef] [PubMed]

19. Salvo, A.M.P.; La Parola, V.; Liotta, L.F.; Giacalone, F.; Gruttadauria, M. Highly loaded multi-walled carbon nanotubes non-covalently modified with a bis-imidazolium salt and their use as catalyst supports. ChemPlusChem 2016, 81, 471-476. [CrossRef]

20. Serp, P.; Corrias, M.; Kalck, P. Carbon nanotubes and nanofibers in catalysis. Cheminform 2003, 253, 337-358. [CrossRef]

21. Tumuluri, K.; Alvarado, J.L.; Taherian, H.; Marsh, C. Thermal performance of a novel heat transfer fluid containing multiwalled carbon nanotubes and microencapsulated phase change materials. Int. J. Heat Mass Transf. 2011, 54, 5554-5567. [CrossRef]

22. $\mathrm{Xu}, \mathrm{B} . ; \mathrm{Li}, \mathrm{Z}$. Paraffin/diatomite/multi-wall carbon nanotubes composite phase change material tailor-made for thermal energy storage cement-based composites. Energy 2014, 72, 371-380. [CrossRef]

23. Liu, X.C.; Osaka, Y.; Huang, H.Y.; Huhetaoli; Li, J.; Yang, X.X.; Li, S.J.; Kobayashi, N. Development of low-temperature desulfurization performance of a $\mathrm{MnO}_{2} / \mathrm{AC}$ composite for a combined $\mathrm{SO}_{2}$ trap for diesel exhaust. RSC Adv. 2016, 6, 96367-96375. [CrossRef]

24. Zhang, G.Q.; Li, Z.; Zheng, H.Y.; Fu, T.J.; Ju, Y.B.; Wang, Y.C. Influence of the surface oxygenated groups of activated carbon on preparation of a nano $\mathrm{Cu} / \mathrm{AC}$ catalyst and heterogeneous catalysis in the oxidative carbonylation of methanol. Appl. Catal. B Environ. 2015, 179, 95-105. [CrossRef]

25. Wan, X.; Wang, H.; Yu, H.; Peng, F. Highly uniform and monodisperse carbon nanospheres enriched with cobalt-Nitrogen active sites as a potential oxygen reduction electrocatalyst. J. Power Sources $\mathbf{2 0 1 7}, \mathbf{3 4 6}, \mathbf{8 0 - 8 8 .}$ [CrossRef]

26. Yuan, D.; Chen, J.; Zeng, J.; Tan, S. Preparation of monodisperse carbon nanospheres for electrochemical capacitors. Electrochem. Commun. 2008, 10, 1067-1070. [CrossRef]

27. Wang, J.; Xie, H.; Xin, Z.; Li, Y.; Chen, L. Enhancing thermal conductivity of palmitic acid based phase change materials with carbon nanotubes as fillers. Sol. Energy 2010, 84, 339-344. [CrossRef] 
28. Wang, B.X.; Zhou, L.P.; Peng, X.F. Surface and size effects on the specific heat capacity of nanoparticles. Int. J. Thermophys. 2005, 27, 139-151. [CrossRef]

29. Chen, L.J.; Zou, R.Q.; Xia, W.; Liu, Z.P.; Shang, Y.Y.; Zhu, J.L.; Wang, Y.X.; Lin, J.H.; Xia, D.G.; Cao, A.Y. Electro-and photodriven phase change composites based on wax-infiltrated carbon nanotube sponges. ACS Nano 2012, 6, 10884-10892. [CrossRef] [PubMed] article distributed under the terms and conditions of the Creative Commons Attribution (CC BY) license (http:/ / creativecommons.org/licenses/by/4.0/). 